Article

\title{
Capri's Touristification. A Millennial Cultural Landscape Reinvented by Luxury Tourism
}

\author{
Giovanna Russo Krauss
}

Architect at Soprintendenza Archeologia Belle Arti e Paesaggio per il Comune di Napoli, 80127 Naples, Italy; giovanna.russokrauss@unina.it

Received: 1 March 2019; Accepted: 21 May 2019; Published: 27 May 2019

Abstract: In recent years the issue of touristification has been progressively discussed in relation to its impact on historic towns. In this regard, physical transformations and gentrification consequences are both issues often addressed. In Italy, consciousness on the subject primarily grew in relation to Florence and Venice, both national cases widely discussed also on newspapers. The awareness of a wider range of cases affected by this problem, from big cities to small holiday destinations, is even more recent. The aim of the present paper is to address Capri's touristification process, which started in the last decades of the nineteenth century and exploded in the second half of the twentieth century, from the point of view of the field of study of history and conservation of cultural heritage and landscape. Therefore, this process and some of its consequences on the island's cultural landscape and identity are thoroughly analyzed. The paper starts with a brief introduction to the island and its history, which is necessary in order to highlight its rich cultural heritage and the slow pace at which Capri has grown over time as a fishermen island to suddenly transforming into a touristic destination during the last century. Finally, the current touristic vocation and the consequences on Capri's natural and built environment are discussed, with the aim of individuating if and why there have already been losses and what should be done to prevent this negative process from going on.

Keywords: Capri; tourism; touristification; conservation; cultural landscape; tourism gentrification; Mediterranean; architecture; heritage; urbanism

\section{Introduction}

The present article has been the first paper from an ongoing research that is currently exploring Capri's touristification phenomenon with the goal of understanding its reasons, individuating the consequences on the island's cultural landscape and identity, and proposing a new and more sustainable path for its touristic exploitation.

When speaking about Italian touristification and overtourism, Florence and Venice immediately come across as national cases that for quite some time have been widely discussed on scientific journals and newspapers. However, recently a new awareness of a wider range of cases affected by this problem, from big cities to small holiday destinations, has grown. In this framework, Capri's touristification process is particularly interesting because, while similar to other cases in terms of gentrification consequences, unlike them its overtourism is due to "Capri's myth", meaning the island's luxury-celebrity identity, and not its cultural landscape, which is being overlooked and therefore endangered. Tourism exploitation and cultural conservation are, therefore, inextricably linked. It is a process that needs to be studied in order to carefully examine the outcomes, both on Capri's identity and on its physical embodiment, of the touristic strategies endorsed by the local administrations and study the necessary corrections. The present state of conservation of Capri's landscape and cultural heritage is a theme of interest that has attracted the attention of many scholars and stakeholders but that has not yet been organically addressed in a multidisciplinary research; therefore, it has currently 
failed to devise virtuous strategies for its preservation, conservation, and enhancement, developing a more sustainable perspective on Capri's tourism. Currently, the point of view of the article is not that of tourism studies, but that of history and conservation of cultural heritage and landscape. Therefore, Capri's touristification process is investigated in order to analyze its consequences on the island's cultural landscape and identity. In the future, the research will expand to include the points of view of experts of tourism studies and economic and political geography. These contributions will allow the formation of a complete picture of the problem in Capri, necessary for the formulation of the right strategies for the preservation and enhancement of the island from a sustainable tourism perspective.

This is the only way to rightly address overtourism [1], which is a global and recent phenomenon that is being progressively discussed both in public debates and in academia. Indeed, the last decades have been marked by a transformation of the touristic phenomenon, in which low-cost flight companies, internet platforms that allow travelers to book their own accommodation and plan their travel without the assistance of travel agencies, as well as home sharing platforms such as Airbnb, have played a significant part. While touristic development is commonly considered desirable for the economy, in recent years a certain awareness has grown on the downside of excessive tourism. The citizens of more and more cities are starting to protest against their hometown's touristification, and studies are being promoted from a sociologic, geographic, anthropologic and touristic point of view. As István Egresi has stated: «Many locations in Europe have been identified for experiencing overtourism today; however, studies on tourist crowding in high-density destinations are still scarce and most of these studies are approached from the perspective of tourists» [2] (p. 703). In addition to this, it seems that architects have been scarcely interested by the issue and their involvement in the debate is very recent. Among architects, urban planners have been the first ones to address overtourism, although from an operative point of view. Then, the impact of overtourism on historic towns has raised the attention of scholars of urban history and conservation, and now in many conferences the issue of touristification is being discussed in relation to its impact on historic towns. In this regard, physical transformation and gentrification consequences are both issues often addressed. In its future development, the research on Capri's touristification will not only aim at benefit Capri's conservation, but will also aim to establish a new multidisciplinary approach to the study of the phenomenon of overtourism, which, to date, academia has addressed in specific and separate studies, with no debates among different disciplines.

The research that has led to the present paper-although still ongoing-is the result of both the study of the rich literature regarding Capri and the elaboration of the open data of some institutional websites, such as that of ISTAT (the Italian National Statistic Institute), regarding demographics and building data, of Mibac (Italian Ministry of Cultural Heritage and Activities), regarding public cultural sites' visitor data, and of Capritourism, regarding Capri's port movement over time and its current touristic facilities. The first paragraphs, which address Capri's history, rely mainly on secondary sources, while the second part of the paper is the main original part of the research, using on site research, analysis of statistical data, recollection and comparisons of historic views, old pictures, and photographs taken by the author over the years. Some informal talks with locals and Neapolitans that have been spending their summer holidays in Capri from the Sixties to the current day are at the base of the research.

\section{Capri: A Millennial Cultural Landscape}

\subsection{Introducing Capri}

The three islands that complete the Gulf of Naples-Capri, Ischia, and Procida-are located at the far end of both sides of the gulf: Capri is on the southern part, visually continuing the Sorrentine Peninsula, while Ischia and Procida are on the northern end, completing the Gulf of Pozzuoli. Although symmetric, among the three islands, Capri is the one with the best-known panorama from the city and its surroundings. Because of Naples facing south, the characteristic profile of Capri, which resembles a 
sleeping mermaid, is visible from most of the panoramic viewpoints of the city and also from many touristic areas south from it, such as the Sorrento and the Amalfi Coasts (Figure 1).

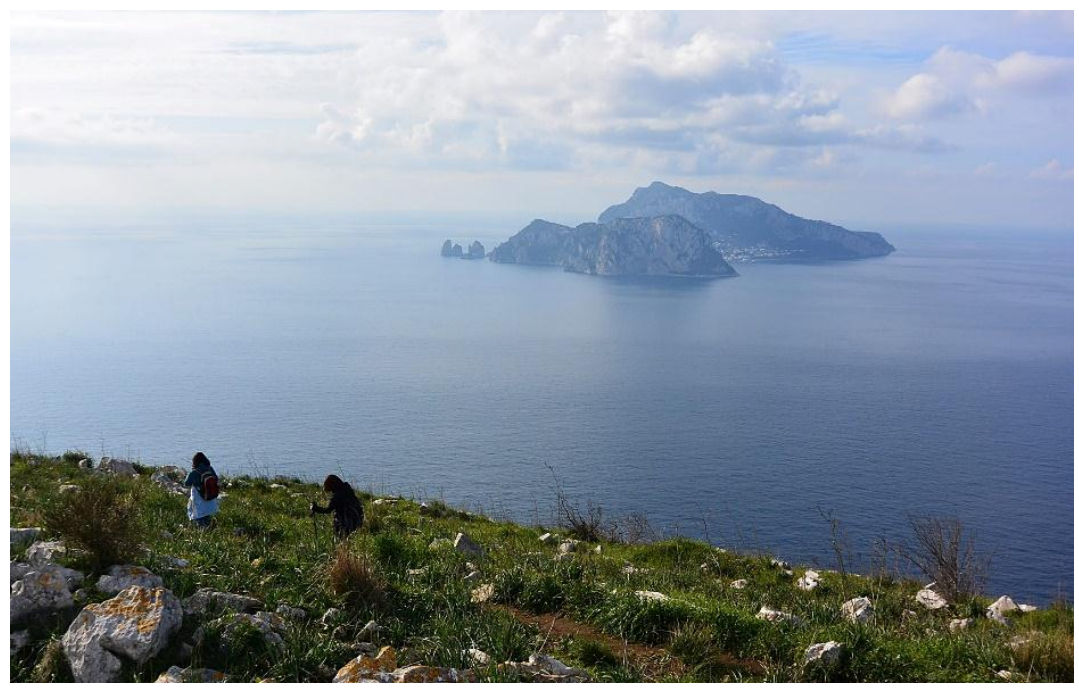

Figure 1. Capri from the Sorrento Coast (Russo Krauss).

The island is mostly famous for its landscape, made of limestone steep precipices over blue and green clear waters. Although very small, it is quite articulated. The main municipality, Capri, is in the central part of the island, a plain between the slopes of Monte Solaro, to the west, and Monte Tiberio, to the east. Between these two mountains, the town descends into the sea in two opposite gulfs: Marina Grande-the location of the harbor-and Marina Piccola, famous for the view of the Faraglioni. Connected to Capri by a single panoramic drive and placed above it, there is the second municipality of the island, Anacapri (Figure 2), which, being on the gentler west slope of Monte Solaro, is entirely hidden from Capri by the vertical east face of the mountain (Figure 3).

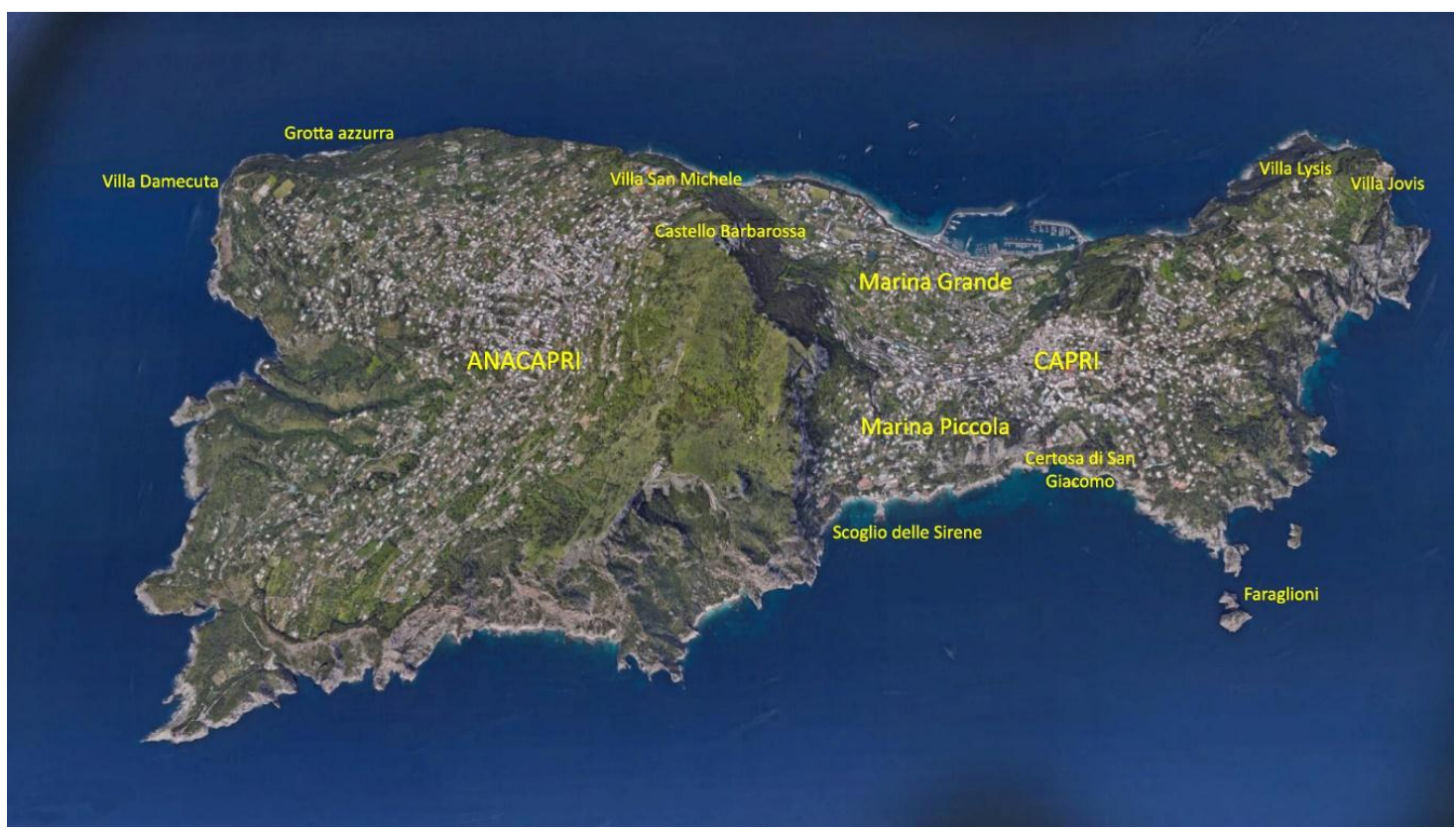

Figure 2. Google earth's picture of Capri elaborated by the author. 


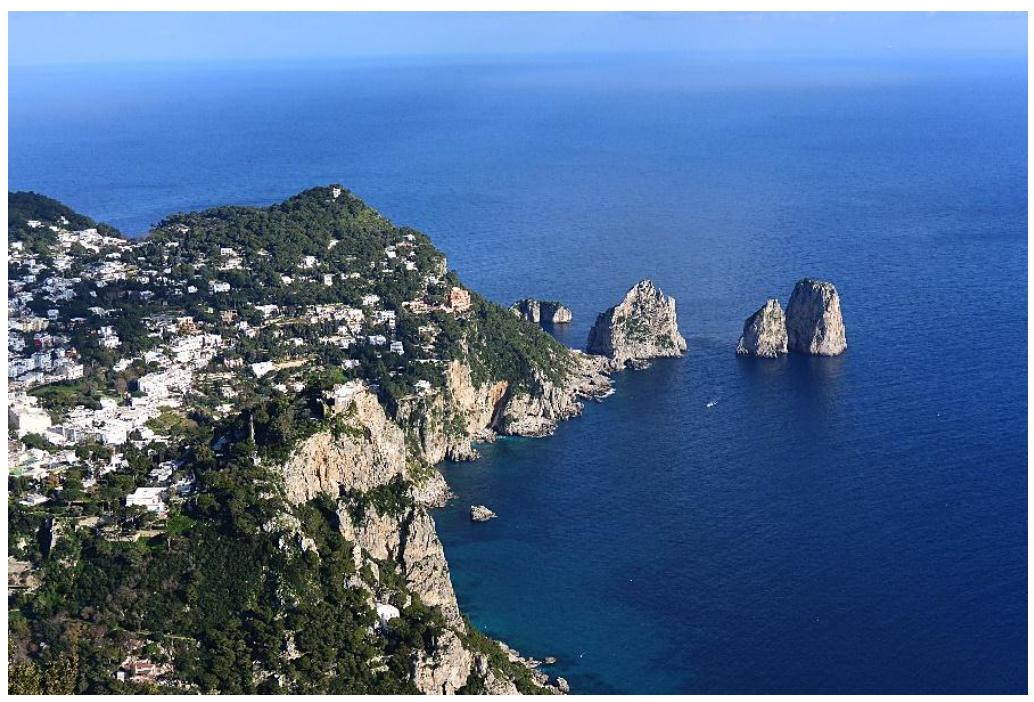

Figure 3. Capri from Monte Solaro (Russo Krauss).

The island is currently one of the best-known Italian holiday destinations in the whole world. The beautiful Mediterranean island, praised for its crystal sea, lush vegetation, and marvelous orographic features is currently the setting of seasonal tourism that revolves around celebrities, luxury, and nightlife. Despite the first settlements dating back to the prehistoric age, the island was not much populated and visited until the Nineteenth Century, when a European elite chose to move in to enjoy a life made of culture and beauty in an extraordinary setting. From that moment on, it underwent many transformations, the main one being its progressive construction. A construction that has proceeded at the same pace as the growth of the island's touristic fortune. Especially the last fifty years, characterized by modern mass-tourism and luxury tourism, have put Capri under the pressure of many physical transformations, necessary for the adaptation of the small delicate island to the needs of the four million tourists per year registered in the last two decades [3].

Capri has indeed become the destination of both the daily pilgrimage of thousands of cruise tourists ${ }^{1}$ and the medium-long stay of rich and famous people, anxious to be part of a legendary and exclusive luxury holiday. Here, night life, five-star hotels and rows of renowned designers' boutiques seem to capture all visitors' attention, whether they are leaving with the evening ship or staying in a magnificent villa. What most present tourists seem to ignore is the unique cultural heritage they are visiting. The island is in fact a cultural landscape, as defined by the World Heritage Convention [4], that links together exceptional panoramas, archaeological remains, centuries-old handcraft traditions, vernacular buildings, as well as beautiful architecture and works of art.

For many centuries, all these features co-existed harmoniously, progressively shaping the island and building its identity. However, Capri's tourism, grown over the last century because of this unique palimpsest, has progressively become independent from the culture of the place, which is no longer the main attractor. As the next section explains, the pristine character of the island and the marvelous landscape brought in Capri an international elite that chose Capri as a holiday destination in which to embrace a culture that was very peculiar to the place. Starting from the 1950s onward, pictures of celebrities walking around the narrow traditional alleys wearing dresses of the moda caprese and tabloids reporting the lives they were living in the small island contributed to the consolidation of Capri's myth, and therefore to its progressive touristic fortune [5]. The cult of celebrities and

1 Between 2010 and 2017, the Azienda autonoma di cura soggiorno e turismo of Capri registered an average of daily passengers that ranged between 16,000 and 20,000 during summer [3]. 
social media, thanks to the indulgence of the local administrations, has strengthened this process and, nowadays, Capri's spontaneous luxury international tourism has become the island's main attractor.

\subsection{From the First Settlements to Italy's Unification}

The island of Capri is a millennial cultural landscape; in fact, thanks to its articulated orography, it has always been inhabited, as it has been demonstrated by numerous prehistoric-age remains [6]. The Greeks lived here for many centuries founding both Capri and Anacapri (the Greek suffice ana means above) settlements connected by the so-called Phoenician Steps, still present today. Firstly property of Neapolis and later of the emperors, the island was particularly dear to the Roman emperor Tiberius who spent the last ten years of his life in Capri, erecting many villas, the most famous of which was Villa Jovis whose magnificent archaeological site can still be visited today (Figures 4 and 5) [7]. During the Middle Ages, the island was constantly attacked by pirates who destroyed many monuments, including the Castello Barbarossa, a fortress dating back to the 9th century, which was never fully rebuilt [8] (pp. 7-22).

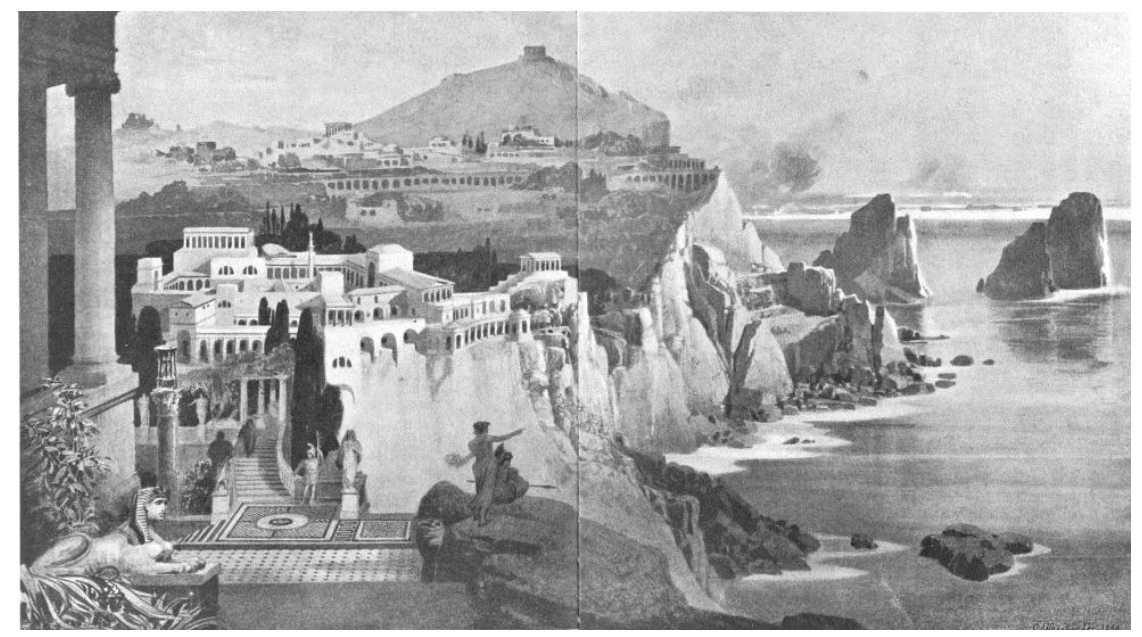

Figure 4. Karl Weichardt, ideal and fictional reconstruction of Tiberius Palace in Capri, 1899.

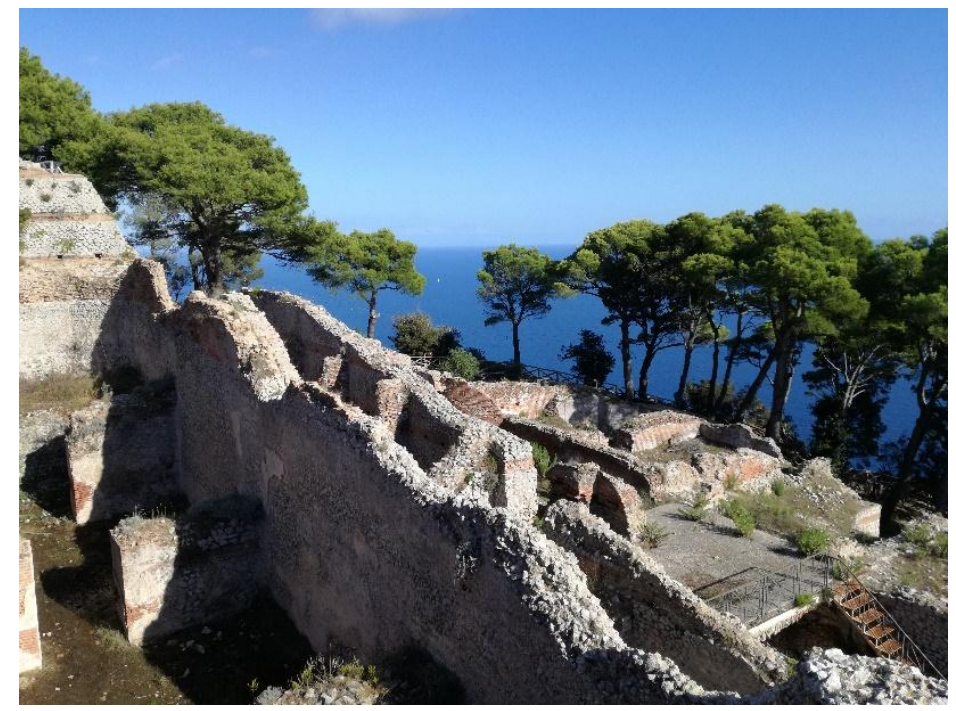

Figure 5. The archaeological remains of Villa Jovis (Russo Krauss).

After a relatively peaceful time, first the Parthenopean Revolution (1799) and then the Napoleonic reign negatively affected Capri's already fragile economy, and at the beginning of Italy's unification, the 
island was extremely poor [9] (pp. 3-7). There were no facilities such as sewers, hospitals, graveyards, nor, as strange as it may seem, was there a harbor, a fact that often cut off the island from the continent. However, its early visitors came here attracted by its very peculiar and fascinating, wild and pristine character [9] (pp. 3-7) (Figure 6).

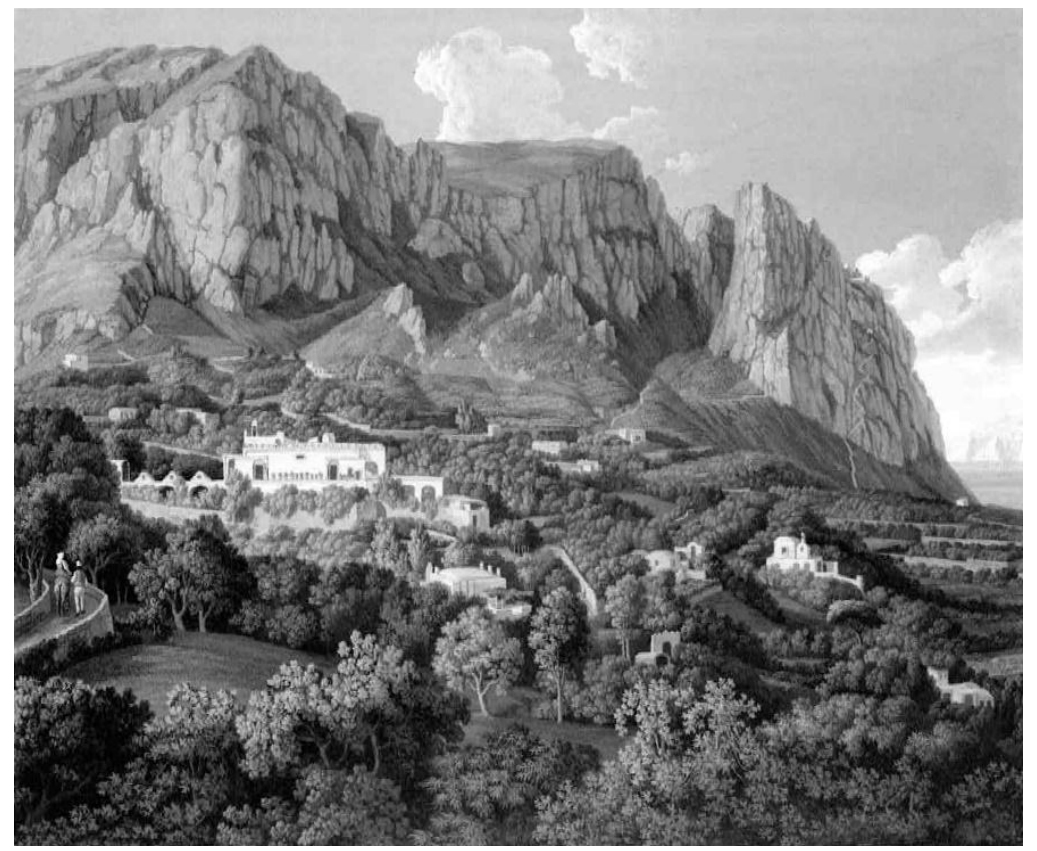

Figure 6. Jakob Philipp Hackert, Il monte Solaro, 1792.

\subsection{Capri's First Urban Transformations}

Italy's unification set the beginning of a new phase, which started with the construction of Marina Grande's harbor (which began in 1869 and lasted many years) and the subsequent implementation of the connections to Naples and Sorrento [8] (p. 23). In 1883, it went on with the re-paving and fitting of the roads-most of them were repaved with quadrangular pavers made of volcanic stone, while the main ones were also widened-and finally, in 1891, the sewer was built [9] (pp. 19-24).

As for the main roads connecting the most important parts of the island, today there are still three of them, providing a connection among Capri, Anacapri, Marina Grande and Marina Piccola. The road that connects Capri to Anacapri was built between 1873 and 1874. Although it finally meant the overcoming of the difficult ascent of the Phoenician Steps, the road also cut through the obsolete town walls and provided a direct connection between Anacapri and Capri's square [9] (pp. 49-53), resulting in the irretrievable alteration of the entrenched character of Capri's old town, which is visible in many historic views, such as the ones by Giacinto Gigante, who depicted the small town behind high walls up on the plain [10-12] [13] (unnumbered pages Disegni capresi di Giacinto Gigante (1806-1876)) (Figures 7 and 8). As for the roads to Marina Grande and Marina Piccola, the first one was built between 1872 and 1877 and the second one between 1897 and 1913, both thanks to Emilio Mayer, an engineer of the Municipality responsible for many of the island's new infrastructures [9] (pp. 53-58). 


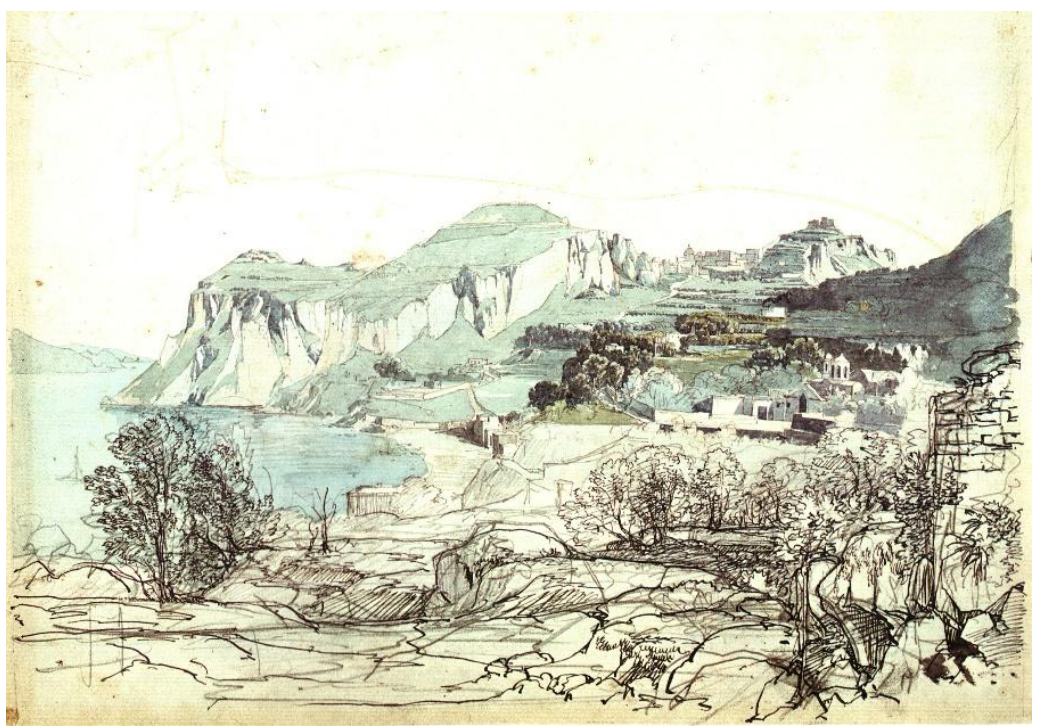

Figure 7. Giacinto Gigante, Capri da occidente, the middle of the 19th century.

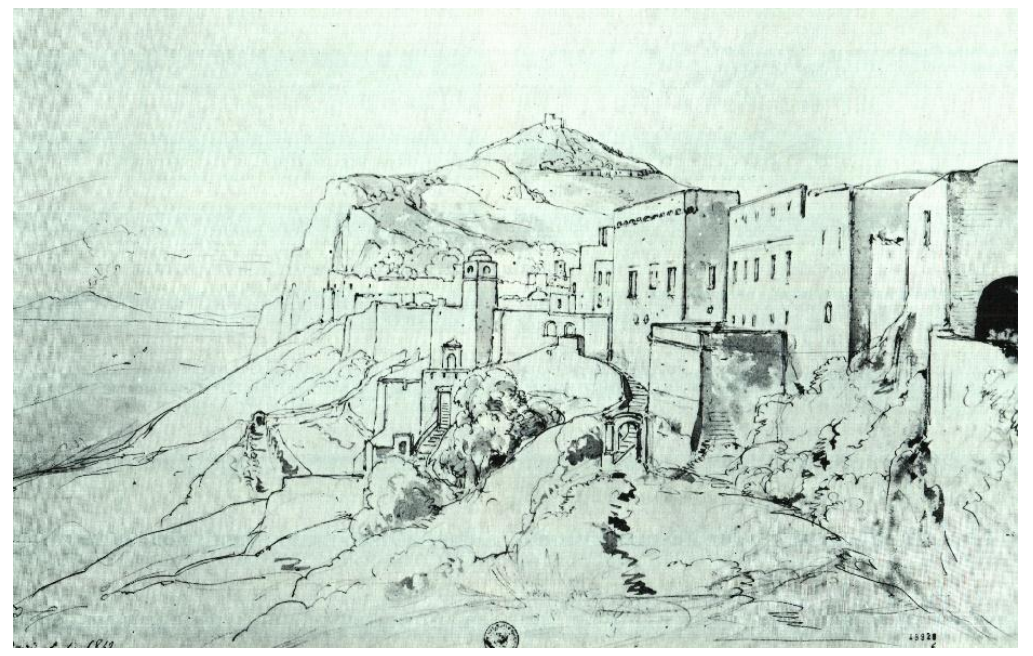

Figure 8. Giacinto Gigante, Veduta del borgo di Capri con il campanile e le mura di piazza, 1842.

The funicular that, since 1907, has provided a direct connection between the port and the Piazzetta, Capri's main square, also represents a very famous and picturesque island facility. After the necessary works carried out by the municipality in the second half of the nineteenth century, this cable car-as stated by Valentina Russo-inaugurated the entry of modernity in Capri and its progressive leaning on tourism as a resource. In fact, the funicular constituted the first transformation of the historic landscape that, far from being a necessity for the islanders, facilitated tourists during their stay. Very soon, in fact, the funicular became an indispensable means of transport for a new kind of visitors, that of modern mass tourism, most of which comes to the island for a day trip [14] (73-75).

\section{The Golden Age of the Enlightened Elite}

\subsection{The Foreigners}

It was only in the 19th century that the island started to become an object of tourism, as it is shown by the progressive multiplying of hotels, from the first three-the Hotel Pagano (currently la Palma) [15] (pp. 31-84), Villa di Tiberio, and Villa di Londra-recorded in 1857 [9] (pp. 25-27), to the current over a hundred hotels and B\&Bs [16], some of which, such as the Quisisana and Tragara 
hotels, have become famous landmarks. This destiny also awaited many villas that foreigners who had chosen to move to the island built for themselves. Among these, it is worth mentioning Villa San Michele - built at the end of the 19th century by the Swedish physician and author Axel Munthe on an archaeological site in Anacapri [17] — and Villa Lysis (Figure 9), built by the French writer Jacques d'Adelswärd-Fersen in 1905 near the archaeological remains of villa Jovis [18].

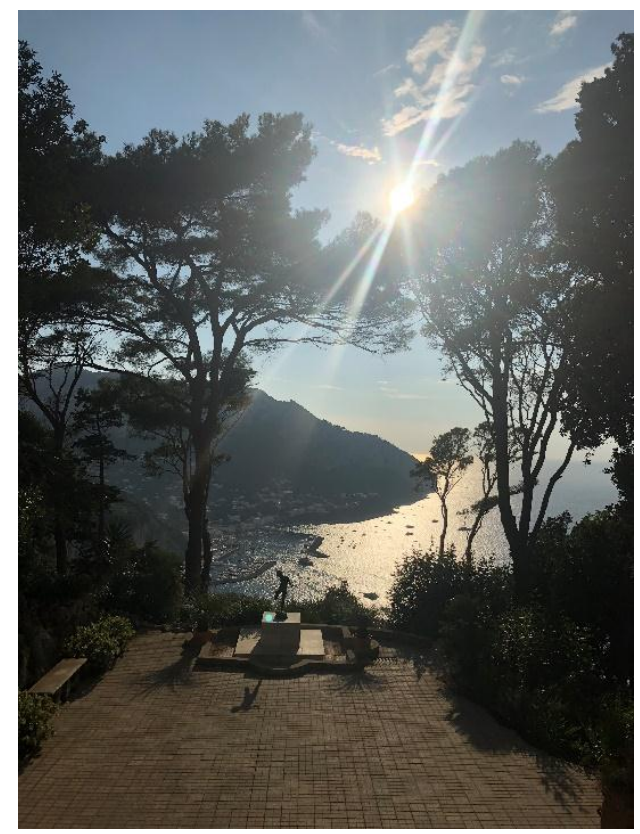

Figure 9. Villa Lysis, the terrace overlooking Marina Grande (Russo Krauss).

At first, Capri was the beloved destination of artists and grand tourers; men that, fascinated by its pristine character, left us numerous paintings and drawings of a landscape now deeply altered. Giacinto Gigante, Achille Vianelli, Consalvo Carelli, and Karl Diefenbach all painted the great beauty of the vernacular vaulted architectures side by side in small aggregates, immersed in vegetation at the foot of stupendous cliffs [19] (Figure 10). Then, before the Italians, curious as it may seem, a European elite, made of noble men, entrepreneurs, and artists "discovered" the island, enriching it, promoting it, and turning it into one of the most international centres of Italy. This was a rapid change, as is indicated by the fact that in 1876 the island had a Protestant church while still lacking in many necessary facilities [9] (p. 28). 


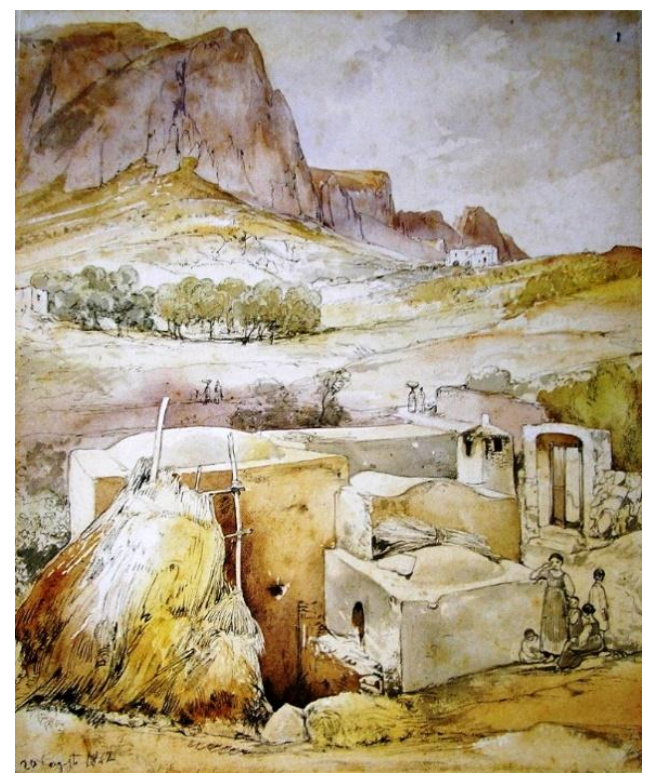

Figure 10. Giacinto Gigante, Casa rustica ai piedi del Monte Solaro, 1842.

This golden age between the last decades of the 19th century and the first ones of the 20th century has been the object of study by many scholars, and it is now detailed in many books, among which, since there is not enough space here to mention them all, we recommend Capri. Immagini e protagonisti by Francesco Caravita di Sirignano and Capri. Frammenti postumi by Lea Vergine [20,21]. However, it is not possible to trace Capri's history of early "tourism" without mentioning the names of some of the people from all over Europe that chose to move to the island: Emil von Behring, recipient of the Nobel prize; lady Blanche Gordon Lennox, who between 1904 and 1945 owned a large portion of San Michele's hill [22] (pp. 22-27); the German painter Karl Diefenbach, who spent the last ten years of his life here; the Russian writer Maxim Gorky, who lived here from 1906 to 1913, hosting Lenin and creating a large Russian community [23]; the German portraitist Allan Willie Allers; the French writer André Gide; and the British writer Norman Douglas, who wrote many pages about the island and was celebrated with the honorary residence [24].

These foreigners deeply cared for Capri, and whether just by living here or by actually promoting architecture for the community or other humanitarian activities, they had a deep impact on the island that today still remembers many of them as illustrious citizens. For example, this relationship of mutual respect is testified by the case of Henry William Gardiner Wreford, correspondent of the Times magazine, to whom a commemorative plaque in the Town hall expresses gratitude for the publicity he gave to the island, that had learnt to count on foreign tourism as an important resource [25]. George Sidney Clark, the British doctor and creator of Hotel Quisisana, and Friedrich Alfred Krupp both received honorary residence, the latter, owner of the well-known German steel company Krupp, due to his promotion of the construction, between 1900 and 1902, by the municipal engineer Emilio Mayer of the famous via Krupp, a scenic road that connects the area of Capri near hotel Quisisana to Marina Piccola (Figure 11). This pedestrian road, a harmonious switchback paved footpath zigzagging in the steep cliff under the Castiglione, has since been widely praised for its beauty, and Roberto Pane-who for many years fought for the protection of Capri's landscape, also writing many articles in the journal Napoli Nobilissma-in his second edition of the book Capri, defined it "an artwork itself" [13] (Unnumbered pages Una strada come opera d'arte), [26] (pp. 491-497), [27] (312-319). 


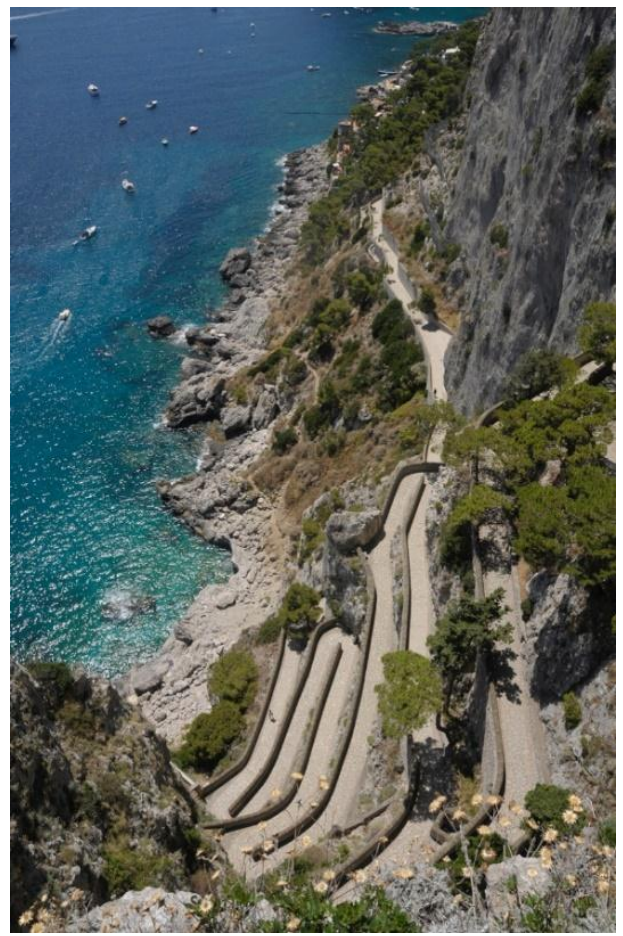

Figure 11. Via Krupp (Russo Krauss).

\subsection{The Local Clans}

In addition to this international intelligentsia, there were also local clans, such as the Paganos or the Cerios, who owned large portions of territory and built hotels, villas, and facilities, contributing to the transformation of the island from a wild and pristine Mediterranean island into a cosmopolitan centre and an international touristic destination. Among these families, it is necessary to mention the names of Ignazio Cerio (1840-1921) and Edwin Cerio (1875-1960), from one of the oldest families of the island, owners of the homonymous palace near the Piazzetta, which dates back to the fourteenth century and currently houses a museum and the library dedicated to Ignazio Cerio [21] (pp. 23-35), [28] (pp. 99-128). Being the medical doctor of Capri, Ignazio promoted many scientific studies regarding the island's history, archaeology, flora and climatic conditions, therefore attracting many scholars, that went to the island to see the outcomes of the excavations and promoting Capri's culture and landscape. His son Edwin was also a man of great culture with many interests. He was an engineer but also a writer, a historian and a botanist [29]. He too deeply loved the island and in 1920 became its mayor, endorsing, in 1922, the well-known Landscape conference for the promotion and safeguarding of the island: a meeting of scholars of the highest repute that, at a time when Capri had been scarcely built (Figure 12), foreseeing what was about to come, had the goal of stimulating the defense of both the Mediterranean landscape and the old town, not only because of its historic architecture but also because of its vernacular buildings [30-32], [33] (pp. 171-178). 


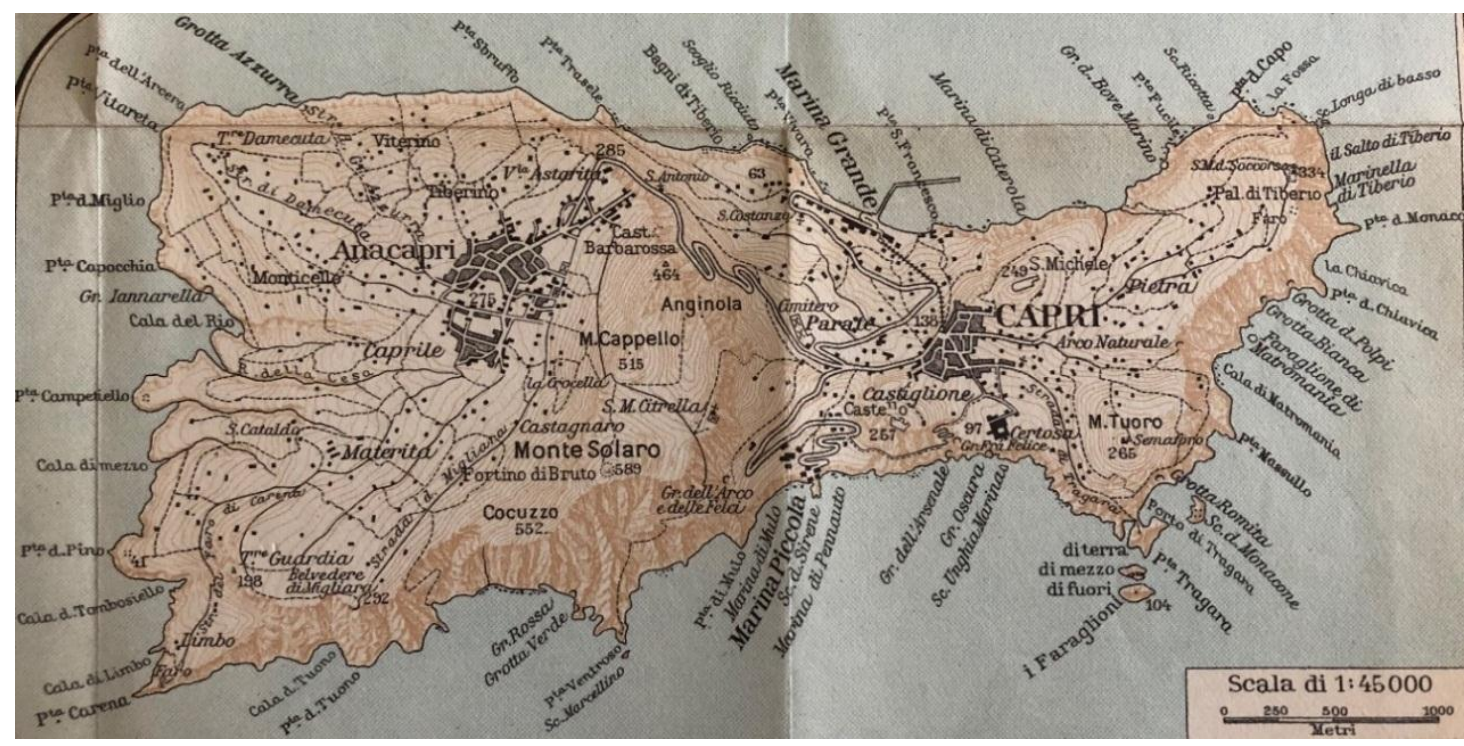

Figure 12. Map of Capri published in the 1938 edition of the Napoli e dintorni Touring Club's guide [34] (p. 449).

Together with the foreigners-Russian, German, French and English noblemen and dandies-these families, that Lea Vergine calls "the Italian dynasties", constituted the upper class of the island, an intellectual caste which, however, did not improve the general condition of the local population [21] (pp. 10-21). The growing presence of foreigners did benefit many islanders, who started to live on tourism, but still left out many others who continued to live on farming and culture. At the time, the island had no water sources and lived on cisterns; therefore, drought was a serious issue that affected house life as well as farming activities, and many who struggled to live under the heavy taxes of the new Italian state emigrated in great numbers to America [9] (pp. 35-36).

\section{Capri's Touristification and Its Consequences}

\subsection{Capri's Attractors}

It is in the second half of the twentieth century that Capri has become a mass tourism destination, globally praised and desired, certainly one of the best-known tourist destinations in the world. In 1955, although Capri's touristification was just beginning, Roberto Pane wrote in his homonymous book that the island had the unfortunate destiny of being too loved. Therefore, it was in danger of becoming «irretrievably conventional and prissy» [13] (p. 5), progressively losing its historic and natural features in order to adapt itself to tourism demand. Sadly, the forewords added in the 1965's edition of the volume [13] (p. 8) confirm the progressive fulfilling of Pane's prophecy, a prophecy still in the making and particularly relevant in today's mass-tourism society.

From the noble men of the end of the 19th century to the artists and politicians between the two wars, it is mainly in the second half of the 20th century that Capri's tourism has definitively changed. Between the 1960s and the 1970s, many international celebrities, such as Liz Taylor and Jacqueline Kennedy (Figure 13), chose the island as a holiday destination in which to embrace a culture that was different from the one they were used to and very peculiar to the island (it is enough to mention the custom of dressing in the typical moda caprese [5]). In the following years, their growing presence was accompanied by the diffusion of the mass tourism phenomenon. In spite of the local artistic and natural heritage, mass tourism was more the result of the presence, and the, although remote, chance to see these public faces $[35,36]$. 


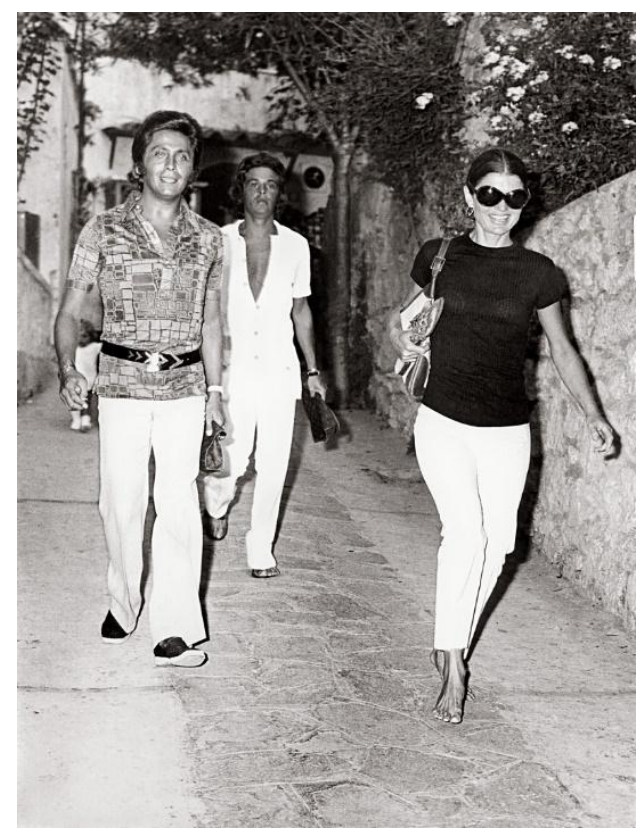

Figure 13. Jacqueline Kennedy with Valentino in Capri, 1970.

Capri is still famous for its marvelous natural features, laden with extraordinary rock formations such as the Faraglioni and the Grotta azzurra, but it also has archaeological sites and numerous monuments and works of art, which, however, do not receive the attention they deserve. Among them, there is certainly the Certosa di San Giacomo (Figure 14), a fourteenth century splendid piece of architecture on top of a cliff facing the Faraglioni, which, together with the ones of Padula and Naples, is one of the only three in Campania [37]. There is also the Chiesa di San Michele Arcangelo in Anacapri, which is entirely paved with maiolica tiles depicting the expulsion of Adam and Eve from the Garden of Eden. These are cultural sites safeguarded by the Italian State that, through the Neapolitan Superintendence, is in charge of their conservation and in most cases manages their promotion and public access.

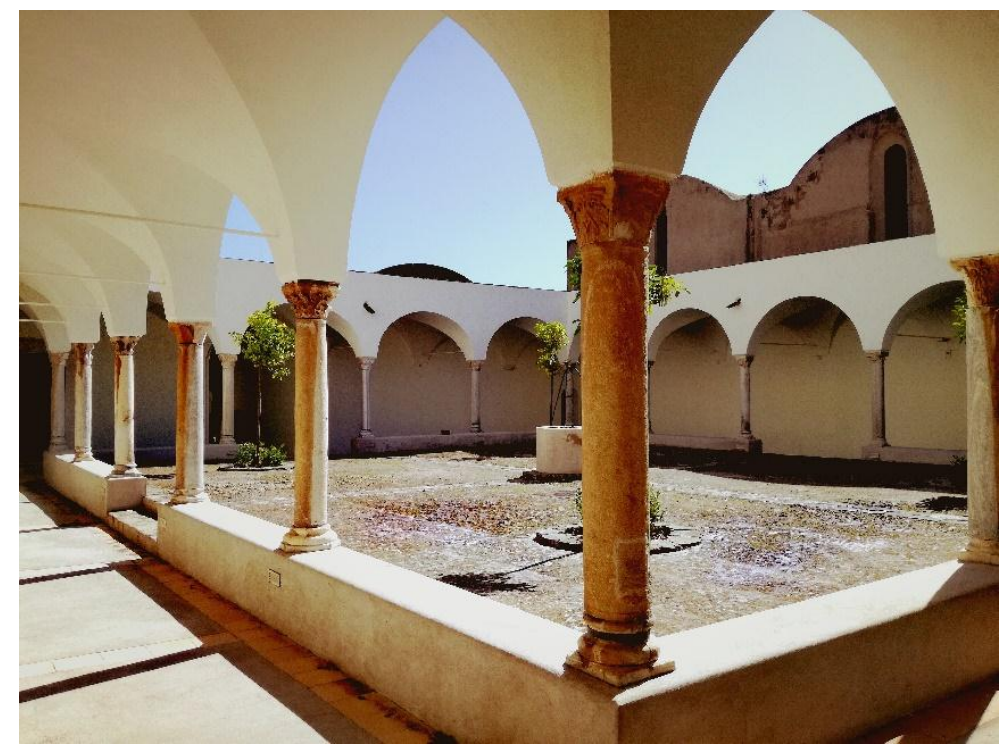

Figure 14. The Certosa di San Giacomo (Russo Krauss). 
Despite this rich cultural heritage, the statistical data collected by the Minister of Cultural Heritage and Activities regarding the island's public cultural sites confirm the discrepancy between the high number of annual tourists and the visitors of the cultural sites. Capri's municipality has an archaeological site of great importance (Palazzo di Tiberio-Villa Jovis) as well as a beautiful monument (the Certosa di San Giacomo) and a museum (Museo del Centro Caprense Ignazio Cerio); however, of the 4,319,157 tourists registered in Capri in 2015, these three sites were visited only by 60,446 people [38].

Despite this cultural heritage, it is clear that a significant part of Capri's tourism relies on the international presence of important names, today mostly celebrities from sports and entertainment, and once artists and cultural elites [35]. Although Capri's natural and artistic identity still constitutes a base for the touristic image of the island, the tourism that it generates and fosters has progressively grown apart from it. Indeed, what were once exclusive touristic facilities that economically exploited the island's beautiful scenery are now often themselves attractors.

This phenomenon, in the present society of the cult of celebrities, has become even stronger. In the new millennium it is fostered by social media that have changed the rules of the game, making the paparazzi unnecessary because both tourists and celebrities constantly communicate their stay on the island to a wider public (Figure 15). This way all visitors-celebrities, holidaymakers and daily visitors from Naples' bay or from traffic cruise-visit the island because of its self-referential luxury industry of tourism, and because they are fascinated by the chance to walk side by side with the celebrities they usually consider out of reach. This is a phenomenon depicted as early as in 1949 in a well-known Italian film, Totò re di Capri, by the Neapolitan comedian Totò.

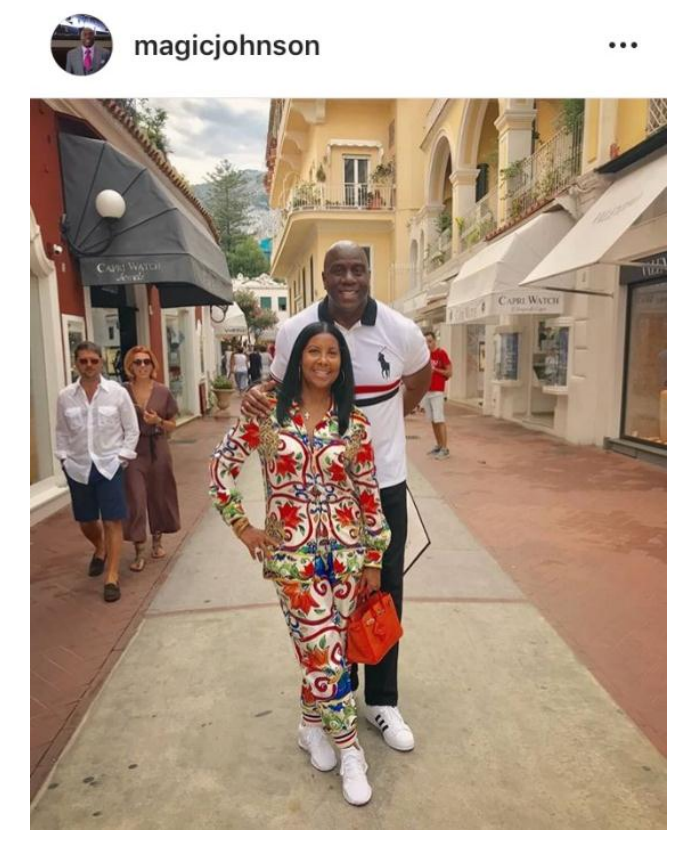

Figure 15. Magic Johnson in via Camerelle in Capri in 2018, Instagram post.

Moreover, the local and national press constantly show people how Capri is the VIP's island, during summer never failing to update people on the latest celebrity stay on the island, showing celebrities hanging out in the usual places: Via Camerelle, that is now the high fashion boutiques' street, the Piazzetta and the famous Anema e core night club. The easiness with which the "common" tourist can visit the very same places in which its favorite celebrity has been photographed by the paparazzi has guaranteed Capri its success, but also its highly impacting touristification and gentrification. In fact, the very few roads where celebrities walk are the ones packed with tourists every summer day, the ones in which the high rental values have drawn away traditional shops to make room for high fashion franchising stores, and in which very expensive restaurants, eager to exploit the myth of 
celebrity-Capri, display countless photographs of celebrities near the entrance dining in that very place or hugging the owner.

\subsection{The Transformation of Capri's Cultural Landscape}

In the century after Italy's unification (1860), Capri and Anacapri's population has constantly grown, and while Capri's population has now been stationary for about 30 years, Anacapri is still growing (Figure 16) [39]. While the population has grown from 1196 people in 1861 to 14,204 in 2016, the island's construction has proceeded independently—the island has 5509 families, but 7108 houses [40]—and at a much faster pace. Therefore, the sporadic villas and hotels built by the enlightened elites of the 19th century, the landmarks and modern monuments with an identity both local and international, timeless and avant-garde, have been obfuscated by the progressive construction of the island [41-44]. As it is indicated in the graphic below (Figure 17), between the 1940s and the 1970s, according to a same trend but at different times, Capri and Anacapri saw the construction of hundreds of new buildings, a phenomenon that has ceased only in recent years [40]. This was because in 1984 the General urban development plans of Capri and Anacapri were finally approved and in 1995 the Superintendence of Naples produced the Piano territoriale paesistico dell'isola di Capri [42], which has guaranteed a better, but not complete, defense of Capri's landscape.

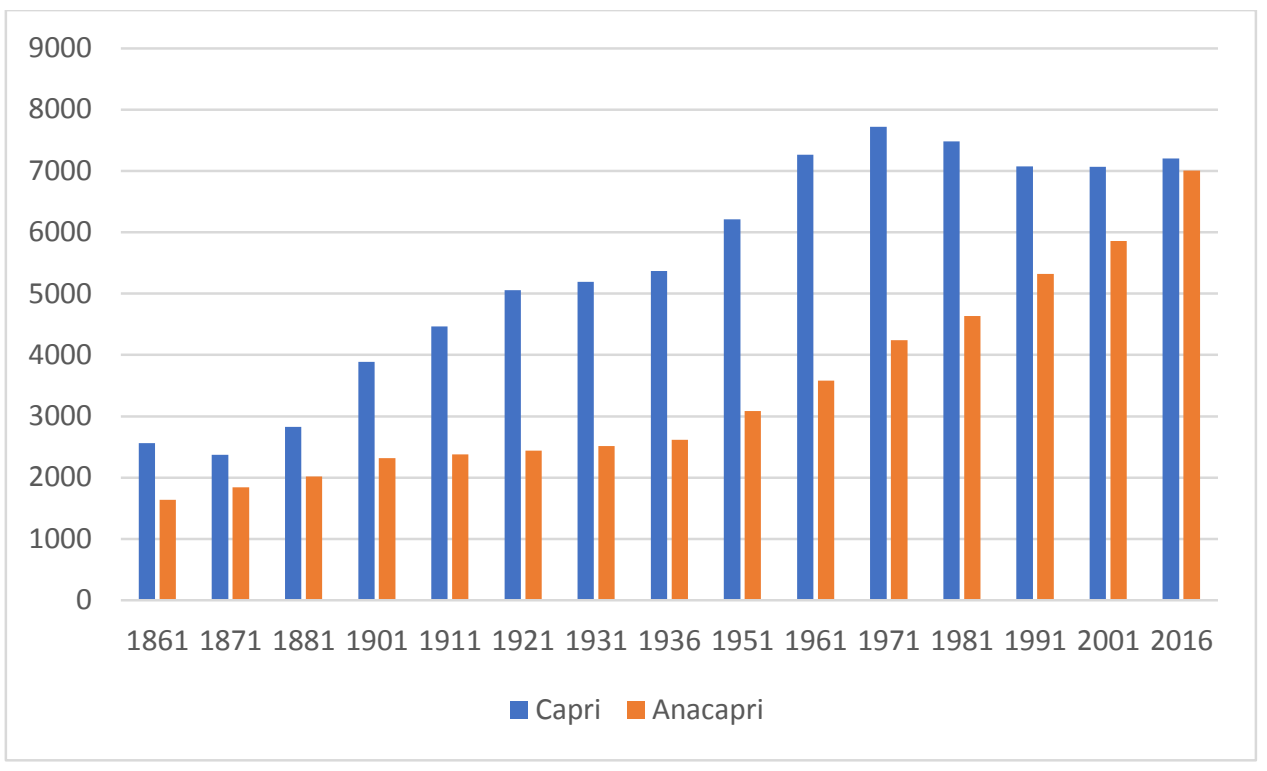

Figure 16. Capri's and Anacapri's population from 1861. Data from http://www.comuni-italiani.it elaborated by the author [40]. 


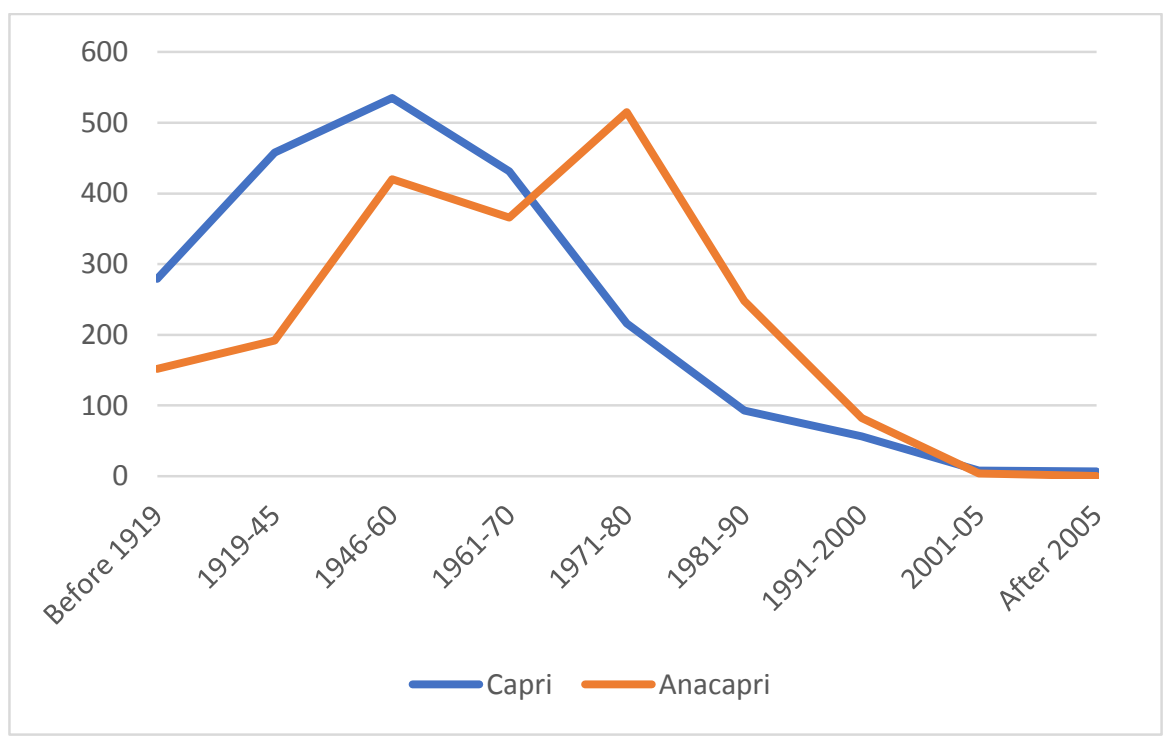

Figure 17. Number of buildings in Capri and Anacapri from 1919. Data from http://italia.indettaglio.it elaborated by the author [42].

Over time, whether legally or in spite of the law, buildings of great dimensions and no artistic value have spread on the island, as in the cases of Hotel Weber Ambassador and Hotel Luna (Figure 18), both in a position that deeply affects the landscape, while the old villas have been progressively enlarged and fragmented, becoming condominiums, such as Villa Discopoli [45] or Villa Torre Saracena.

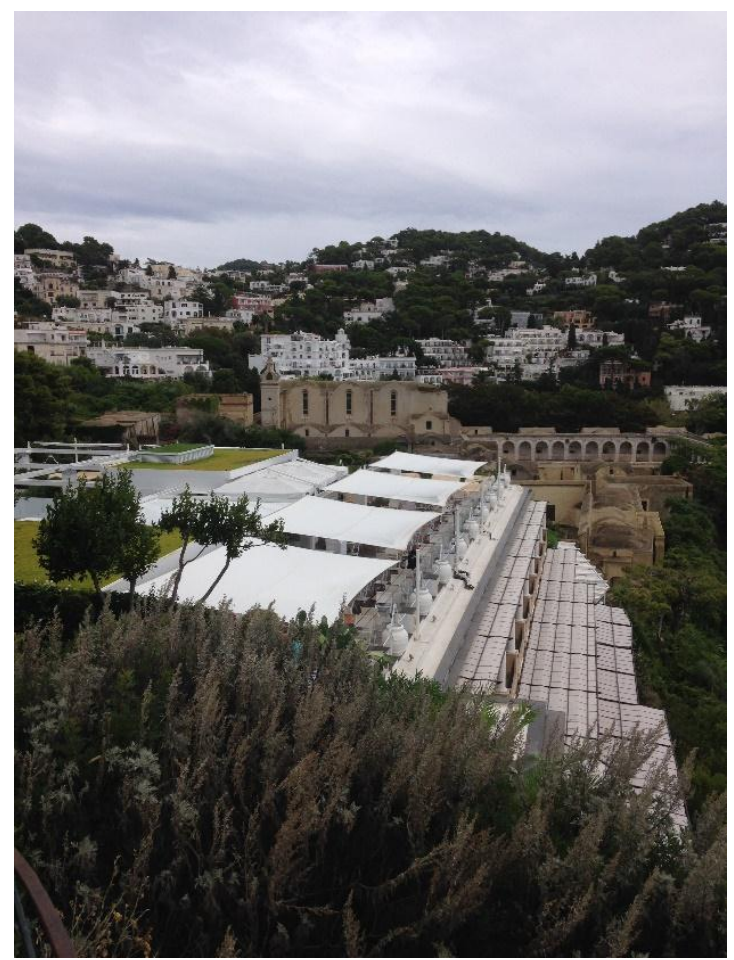

Figure 18. The architecture of Hotel Luna near Certosa di San Giacomo has negatively affected the view from the island and within it (Russo Krauss).

The coastline, which had to change in order to be adapted to the demands of the bathers, has however, suffered the worst alteration. The island, in fact, has almost no beaches, being mainly made 
of high cliffs, and bathing establishments had to be terraced pieces of architecture; therefore, local entrepreneurs cut the cliff or cemented fragmented rocks. This happened in the cases of Scoglio delle Sirene (Figure 19), la Fontelina and Luigi ai Faraglioni (the last two positioned on both sides of the Faraglioni), all of which have altered unique rock formations extended over the sea.

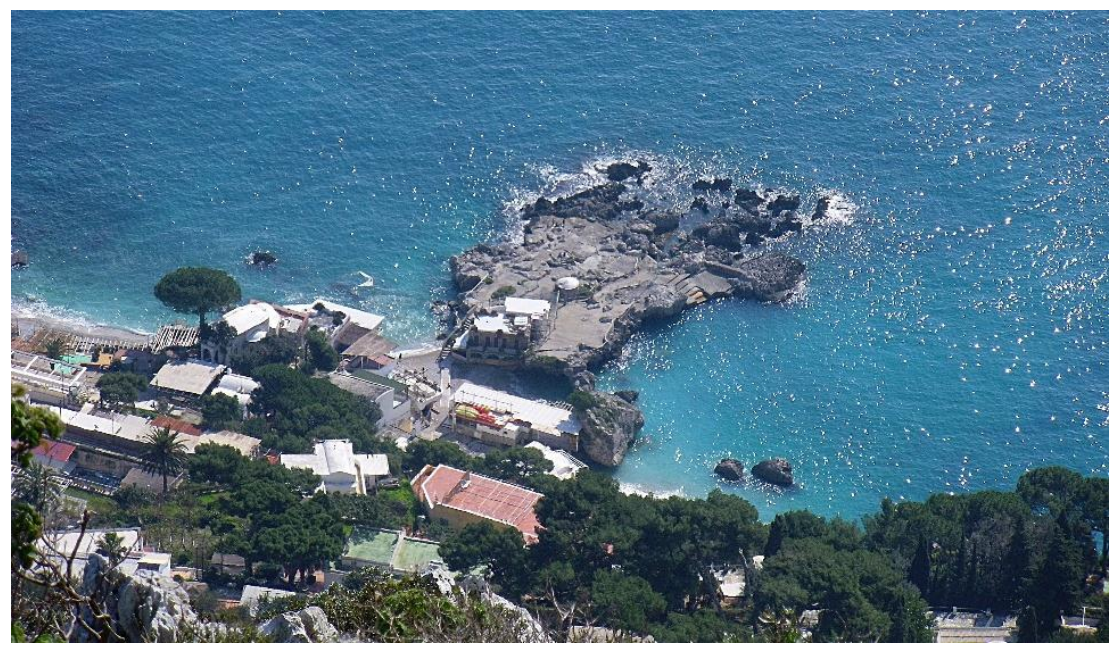

Figure 19. The Scoglio delle Sirene beach service in Marina Piccola has covered the unique rocks of the coastline with concrete (Russo Krauss).

As for other islands deriving profit from tourism (such as the other island of the Gulf of Naples, Ischia), it is sad to point out that many of these transformations were carried out with the connivance of the local administration, and that thanks to tourism it has become rapidly rich, in deep contrast with the poverty and the loans the same municipality had to take out after Italy's unification [9] (pp. 37-44).

Over the last fifty years, many lawsuits were opened to inspect and persecute the violation of building licenses. One of the most recent and famous ones was over the bathing service Nettuno, which is in one of the most famous areas and near one of the most important natural monuments of the island, the Grotta azzurra. It was indeed only in 2018 that an enquiry brought its preventive seizure, after, however, many years of progressive enlargement from a bathing establishment to a hotel had meant the alteration of the coastline through the cutting of the ridge [46].

\section{Capri's Current Identity: Luxury Tourism and Gentrification}

As Capri's touristic image moved from unique Mediterranean cultural heritage and landscape to must-see luxury and nightlife summer destination, so did the island. The high economic interests on the island have led the local administration to not interfere with private initiatives- and sometimes to foster it even if it damages the island's material and immaterial heritage --, and privates, of course, prefer to lean on Capri's luxury, rather that cultural, identity. This has endangered part of the heritage and has led to the flattening of Capri's image. Just consider the progressive substitution of small diners and traditional workshops, both in wider streets and narrow alleyways, by elegant restaurants and big serial flagship stores, with no connection to the location, all closed at the end of the tourist season. A mass tourism globalization process indulged by the local administration, pursuing increasingly touristic incomes with no regard for the fact that they are limited to the summer season (Figure 20). 


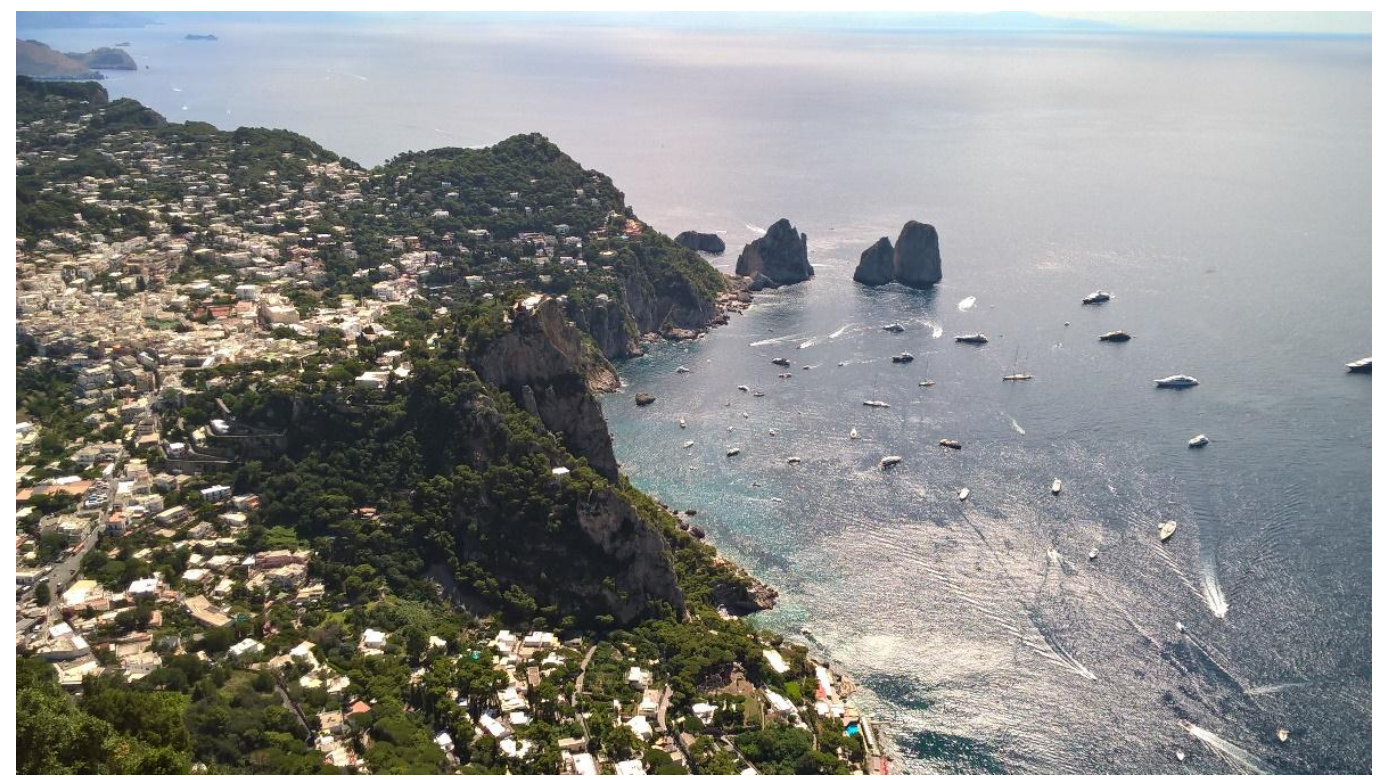

Figure 20. Capri from Monte Solaro (Russo Krauss).

Trying to keep up with the rapid evolution of society's customs and touristic standards, the island has changed much more in the last seventy years than it did in the previous centuries. Indeed, the local administration has allowed the progressive occupation of green areas, the fragmentation of historic villas, the replacement of traditional shops with international boutiques, and the building of out of scale hotels, a phenomenon that has raised the opposition of environmental associations that, however, have failed to curb the phenomenon [47]. Today, on a relatively small area (Capri is 400 hectares and Anacapri is 636 hectares) there are 59 hotels (three ${ }^{* * * *} \mathrm{~L}$, seven ${ }^{* * * *}$, twenty-four ${ }^{* * * *}$, sixteen ${ }^{* * *}$, three **, six *), 3 residences, 30 furnished rooms, 104 rental vacation houses, 93 B\&Bs, and one holiday farm. This means that on 1036 hectares there are 209 accommodation facilities, almost 5 accommodation facilities per hectare [16]. If we consider that there are also 124 restaurants, 15 bathing establishments, 14 nightclubs and 9 Spa and Beauty, it becomes clear how much Capri has devoted itself to tourism, especially luxury tourism, regardless of the impact on its landscape and identity.

On top of this, it has to be pointed out that a huge gentrification process has invested the island and that the estate values are so high that locals are slowly prompted to leave. The average price of house sales $\left(9850 € / \mathrm{m}^{2}\right)$ is approximately $435 \%$ higher than the regional average listing $\left(1800 € / \mathrm{m}^{2}\right)$, and it is also approximately $338 \%$ higher than the provincial average listing $\left(2250 € / \mathrm{m}^{2}\right)$ [48]. It is clear that the local population is paying the high price of Capri's touristic fortune. Even if many families get a job in the tourism industry, in the cold season they must live with the money they make during summer, but in a town that is nowadays designed for tourists and not citizens. Shops of essential goods are difficult to find, because they have been replaced by expensive boutiques and restaurants which, as mentioned, are all closed during winter.

The high number of tourists that during summer take over Capri, flooding few small places, demonstrates that most people visiting the island in search of luxurious eccentricities, panoramic pools, high fashion flagship stores and nightlife seem to be completely unaware of the true, or maybe the deeper, identity of Capri: that of a Mediterranean island, with its typical vernacular architecture and traditions; that of a part of the Gulf of Naples, with which it shares history and art; that of a cultural center, fully recognized between the 19th and 20th centuries, when it became a place in which the highest minds went to rest and gather, exchanging opinions and ideas and experimenting with art. Numerous scholars and enthusiasts have recently dedicated studies to these identities, publishing books and articles on Capri's nature, ancient and modern history, but also on its iconography, traditional architecture, myths, citizens, handcraft, and typical tailoring. However, the copious literature is just as 
ignored by most people as the plaques that should signal to tourists the events that occurred or the old roots of places that are instead overlooked by passers-by.

The research carried out to this moment demonstrates that in less than 150 years Capri has undergone a dramatic transformation. After being a typical, although extraordinarily beautiful, Mediterranean island for many centuries, it has become a beloved destination for Grand Tourers and artists, a new home for intellectuals and entrepreneurs who moved to Capri because of its art and landscape. The spark of tourism initially benefited the island, allowing the building of necessary infrastructure, but also enriched it with new beautiful architecture. The Landscape conference held on the island in 1922 demonstrates that the dangers of the uncontrolled progress of the phenomenon were foreseen by some intellectuals. These dangers were emphasized by Roberto Pane in his book Capri. He wrote in both 1955 and 1965's forewords how high economic interests were progressively building the green island and altering its cultural heritage. In the 1965's forewords he lamented how the touristic industry kept on cementing green areas without realizing that tourists would stop coming to Capri if its natural beauty was irretrievably altered [13] (p. 9). This prediction turned out to be wrong because what Pane could not foresee was the self-referential luxury-tourism industry that in the following fifty years would grow in Capri.

Capri's touristification shows some similarities with other cases, such as the ones of Dubrovnik and Venice, both small historic towns affected by the increasing fortune of cruise ships and day-trips by coaches, which led to a high concentration of tourists in small areas and in specific periods of the year and hours of the day. However, if both cities' tourism heavily relies on their cultural identity of artistic historic towns, Capri's one has changed over the years, and in becoming independent from Capri's cultural landscape it has consequently endangered its preservation even more.

\section{Conclusions}

The present research shows how tourism initially benefited Capri and its cultural landscape, progressively shaping it and enriching it with art and culture. Then, tourism itself became a threat to the conservation of this cultural landscape. Precursors of this are to be found in the 1922 Landscape conference, when the necessity of a regimentation of the touristic exploitation of the island was firstly addressed. The turning point, however, was after War World II, when luxury tourism grew and became the attractor itself. From this moment on, Capri underwent a physical and immaterial impoverishment. On the one hand, its landscape and built heritage were altered by the transformations carried out by the tourism industry; on the other, its historic identity was obfuscated by that of "Capri the VIP-island". It has therefore become much more important to satisfy the growing demands of the present global luxury tourism (through the progressive construction of out of scale hotels, the fragmentation of historic villas, the spreading of franchising boutiques and concrete bathing services) than to preserve a unique landscape and cultural heritage.

Despite the current rich scientific literature, constantly widening the knowledge on Capri's history and culture with specific research, the image of Capri has progressively transformed into that of a luxurious leisure destination, and it appears that this spontaneous process, due to enormous economic interests and thanks to a complex legislation difficult to implement, has not been regulated or controlled by the administration, which, on the contrary, has grown dependent on the huge incomes of the celebrity-Capri commercial product. Many intellectuals and environmental associations such as Italia Nostra and WWF have raised consciousness on Capri's transformation, and over the years many times the national press discussed the phenomenon. Public institutions, such as the local Superintendence, Capri's and Anacapri's administrations, entrepreneurs, private companies, citizens and tourists are all stakeholders of this phenomenon in which acts and laws create a picture of great complexity that will be further investigated in future research.

The research will deepen the reasons behind the lack of protection of Capri's cultural heritage within the process investigated in the present study. The author's point of view of history and conservation of cultural heritage and landscape will be integrated with the contributions of scholars of 
sociology, geography, and tourism studies, placing the research in a wider, multidisciplinary frame. This new approach will guarantee a deeper understanding of the complex phenomenon, a condition indispensable to performing the actions necessary to prevent its negative consequences to continue. Although peculiar, Capri might constitute a case study that, once compared with other similar cases, could benefit other overtourism destinations such as the historic towns of Venice and Florence, but also Cortina d'Ampezzo in the Unesco's Dolomites, which is also a cultural landscape suffering the consequences of seasonal luxury tourism.

In conclusion, although it is already clear that it is necessary to work toward the protection of Capri's cultural heritage and the recovery of its old identity, we should accept that nowadays Capri is both a Mediterranean historic island and a capital of global luxury tourism. While currently the latter is prevailing and slowly destroying the former, both identities, if embraced as equal and regulated as they should, paying greater attention to tourism sustainability, can live together, mutually enriching each other.

Funding: This research received no external funding.

Acknowledgments: I am thankful to everyone who has supported the creation of this work. Special thanks to my mentor Andrea Pane, Associate Professor of Architectural Conservation, who shares with me a great love for Capri and encouraged me to start this research. I was strongly inspired by his studies and his ability to keep together so many fields of research, I hope to continue it with his collaboration. I also thank Dionisia Russo Krauss, Associate Professor of Economic-Political Geography, who provided insight and expertise that benefited the research and who will contribute to its future progress. My gratitude goes to Katerina Chatzikonstantinou (Aristotle University), Castro Brunetto Carlos Javier (Spain-Universidad de La Laguna) and David Martín López (Universidad de Granada) for chairing a very interesting session at the 2018 EAUH international conference and for proposing this special issue of Heritage. Katerina Chatzikonstantinou has been very supportive of my work and for this I am grateful. I also thank my editor Josh $\mathrm{Gu}$ for the patience and availability he has shown to me during the long process of refinement of the manuscript. Finally, all my gratitude goes to the four anonymous reviewers for their comments, their useful suggestions helped me improve the article and the future of the research.

Conflicts of Interest: The author declares no conflict of interest.

\section{References}

1. Milano, C.; Cheer, J.M.; Novelli, M. Overtourism: A Growing Global Problem. Available online: https: //theconversation.com/overtourism-a-growing-global-problem-100029 (accessed on 13 April 2019).

2. Egresi, I. “Tourists Go Home!"- Tourism Overcrowding And “Tourismophobia” In European Cities. (Can Tourists And Residents Still Co-Habitate In The City?). Habitation Tactics. Imagining Future spaces in architecture, city and landscape. In Proceedings of the TAW International Scientific Conference, Vladivostok, Russian, 2-4 October 2018; Pedata, L., Porfido, E., Rossi, L., Eds.; Polis Press: Tirana, Albania, 2018; pp. 701-714.

3. Azienda Autonoma di Cura Soggiorno e Turismo. Capri, Comparison of Port Movement 1999-2018; Azienda Autonoma di Cura Soggiorno e Turismo: Capri, Italy; Available online: http://www.capritourism.com/en/ statistical-data (accessed on 14 April 2019).

4. UNESCO. Operational Guidelines for the Implementation of the World Heritage Convention; UNESCO World Heritage Centre: Paris, France, 2012; pp. 13-14.

5. Cirafici, A.; Cirillo, O. Sguardi su Capri. Moda e rappresentazioni di un'icona dell'immaginario contemporaneo. In Delli Aspetti de Paesi. Vecchi e Nuovi Media per l'Immagine del Paesaggio, Costruzione, Descrizione, Identità Storica; Berrino, A., Buccaro, A., Eds.; Cirice: Naples, Italy, 2016; Volume I, pp. 1243-1253.

6. Federico, E.; Miranda, E. (Eds.) Capri Antica. dalla Preistoria alla Fine Dell'età Romana; Edizioni la Conchiglia: Capri, Italy, 1988.

7. Pelosi, A. Percorsi Archeologici Dell'isola di Capri; Edizioni la Conchiglia: Capri, Italy, 2003.

8. Colletta, T. (Ed.) Capri (Napoli); Edizioni Scientifiche Italiane: Naples, Italy, 1989.

9. De Angelis Bertolotti, R. Capri dal Regno D'Italia Agli Anni del Fascismo; Editoriale scientifica: Napoli, Italy, 2001.

10. C'era una Volta Capri. Un Secolo di Immagini 1857-1957; Electa: Napoli, Italy, 1988.

11. Fino, L. Capri Nelle Stampe. Vedute Costumi e Scene di Vita Popolare; Arte Tipografica: Naples, Italy, 1990. 
12. Soprintendenza per I Beni Artistici e Storici della Campania. L'immagine di Capri, (Certosa di San Giacomo, 1980-1981); Società Editrice Napoletana: Naples, Italy, 1981.

13. Pane, R. Capri; Neri Pozza: Venezia, Italy, 1954; Gallina editore: Naples, Italy, 1982.

14. Pane, A.; Russo, V. Risalire nel golfo di Napoli, dal Vesuvio a Posillipo: le funicolari tra storia e conservazione. In Ascensores y Funiculares del Mundo, Congreso de Patrimonio Industrial (Santiago-Valparaiso, Chile, 14-16 Abril 2011); Rettig, J.M., Cordeiro, J.M.L., Greco, A., Eds.; Universidad Internacional SEK: Santiago, Chile, 2011; pp. 69-89.

15. Kawamura, E. Alberghi Storici Dell'isola di Capri: una Storia Dell'ospitalità tra Ottocento e Novecento; Edizioni la Conchiglia: Capri, Italy, 2005.

16. Capritourism.it. Available online: http://www.capritourism.com/it/accommodation (accessed on 13 April 2019).

17. Munthe, A. La Storia di San Michele; Garzanti: Milan, Italy, 1944.

18. Schmidlin, P. Gli Amori e i Dolori di Villa Lysis; AMEDIT: Vicenza, Italy, 2016.

19. Alisio, G.C. (Ed.) Capri Nell'ottocento. Da meta Dell'anima a Mito Turistico; Electa Napoli-La conchiglia: Naples-Capri, Italy, 1995.

20. Caravita di Sirignano, F. Capri. Immagini e Protagonisti; Società Editrice Napoletana: Naples, Italy, 1984.

21. Vergine, L. (Ed.) Capri 1905/1940. Frammenti Postumi; Edizioni la Conchiglia: Capri, Italy, 1993.

22. Barbato, G. Capri. Il Monte San Michele e la Chiesa de la Croce; Youcanprint: Capri, Italy, 2013.

23. Senatore, F. Umberto Zanotti Bianco e gli esuli russi di Capri. In Conoscere Capri; Amitrano, M., Federico, E., Fiorentino, C., Eds.; Oebalus: Capri, Italy, 2006; pp. 109-115.

24. Douglas, N. La Terra delle Sirene; Edizioni Scientifiche Italiane: Naples, Italy, 1972.

25. Ciuni, R. Lettere al "Times" da Capri Borbonica: le Corrispondenze di Henry Wreford che Mutarono L'opinione Politica d'Europa sul Regno delle Due Sicilie; Edizioni la Conchiglia: Capri, Italy, 2011.

26. Giusti, M.A. Una strada come opera d'arte. Visioni, montaggi, valori di paesaggio nella ricerca di Roberto Pane. In Roberto Pane tra Storia e Restauro. Architettura, Città, Paesaggio; Casiello, S., Pane, A., Russo, V., Eds.; Marsilio: Venezia, Italy, 2010; pp. 490-497.

27. Picone, R. Capri. Mura e volte. Il valore corale degli ambienti urbani nella riflessione di Roberto Pane. In Roberto Pane tra Storia e Restauro. Architettura, Citta, Paesaggio; Casiello, S., Pane, A., Russo, V., Eds.; Marsilio: Venezia, Italy, 2010; pp. 312-319.

28. Sandomenico, C. Leggere Capri. Bibliografia Dell'isola di Capri; Edizioni la Conchiglia: Naples, Italy, 1993.

29. Nastri, A. Edwin Cerio e la Casa Caprese; Clean: Naples, Italy, 2008.

30. Cerio, E. (Ed.) Il Convegno del Paesaggio; Edizioni delle Pagine Dell'isola di Edwin Cerio: Capri, Italy, 1923.

31. Cantone, G.; Fiorentino, B.; Sarnella, G. Capri la Città e la Terra; Edizioni Scientifiche Italiane: Naples, Italy, 1982.

32. Mangone, F. Il paesaggio di Capri: immaginari e tutela tra Ottocento e Novecento. In La Baia di Napoli. Strategie Integrate per la Conservazione e la Fruizione del Paesaggio Culturale; Aveta, A., Marino, B.G., Amore, R., Eds.; Artstudiopaparo: Naples, Italy, 2017; Volume I, pp. 223-227.

33. Mangone, F. Il Convegno di Capri: architettura e paesaggio nel primo dopoguerra. In Professionisti Città e Territorio. Percorsi di Ricerca tra Storia Dell'urbanistica e Storia Della Città, Atti Della Giornata di Studio (Reggio Calabria, 24 Settembre 1999); Adorno, S., Ed.; Gangemi: Roma, Italy, 2002; pp. 171-178.

34. Bertarelli, L.V. Guida d'Italia del Touring Club Italiano. Napoli e Dintorni; Touring Club Italiano: Milan, Italy, 1938; pp. 471-489.

35. Cetti Serbelloni, M. Cinquant'anni di Turismo a Capri. La Sacralità Dell'immagine e la Profanazione del Territorio; Edipuglia: Modena, Italy, 2003.

36. Stazio, M. Le culture della cultura. Le culture di un turismo "insostenibile": il caso Capri. In Il Turismo Sostenibile: Opportunità e Rischi; Romita, T., Alvarez Sousa, A., Nocifora, E., Ercole, E., Iakovidou, O., Pieroni, O., Ruzza, C., Savoja, L., Eds.; Università della Calabria: Lunde, Italy, 2010; pp. 119-130.

37. Di Stefano, R. La Certosa di San Giacomo a Capri; Edizioni Scientifiche Italiane: Naples, Italy, 1982.

38. Imuseiitaliani.it. Available online: http://imuseiitaliani.beniculturali.it/sii//statistiche (accessed on 13 April 2019).

39. Russo Krauss, D. Dinamiche demografiche e sviluppo turistico nell'isola di Capri. In Studi e Ricerche Socio-Territoriali; Associazione Culturale Sviluppo e Benessere Onlus: Naples, Italy, 2013; Volume 3, pp. $25-48$.

40. Comuni-Italiani.it. Available online: http://www.comuni-italiani.it (accessed on 13 April 2019).

41. Mangone, F. Capri e Gli Architetti; Massa: Naples, Italy, 2004.

42. Italia.Indettaglio.it. Available online: http://italia.indettaglio.it (accessed on 13 April 2019). 
43. Piano Territoriale Paesistico Dell'isola di Capri. Off. J. Gen. Ser. 1996, 9, 36.

44. Mangone, F. L'isola dell'architettura. Capri in età contemporanea e le origini del mito mediterraneo. In Architettura e Paesaggi Della Villeggiatura in Italia tra Ottocento e Novecento; Mangone, F., Belli, G., Tampieri, M.G., Eds.; Franco Angeli: Milan, Italy, 2015; pp. 237-255.

45. Verde, P.C. Architettura a Capri dall'Oriente al Mediterraneo. In L'orientalismo Nell'architettura Italiana tra Ottocento e Novecento; Giusti, M.A., Godoli, E., Eds.; Maschietto \& Musolino: Florence, Italy, 1999.

46. Repubblica.it. Available online: https://napoli.repubblica.it/cronaca/2018/06/07/news/anacapri_sequestrato_ il_lido_nettuno_vicino_alla_grotta_azzurra-198395987 (accessed on 13 April 2019).

47. Corriere della Sera.it. Available online: https://www.corriere.it/speciali/bruttaitalia/capri/rapporto_wwf/doc. htm (accessed on 13 April 2019).

48. Mercatoimmobiliare.it. Available online: https://www.mercato-immobiliare.info/campania/napoli/capri.html (accessed on 13 April 2019).

(C) 2019 by the author. Licensee MDPI, Basel, Switzerland. This article is an open access article distributed under the terms and conditions of the Creative Commons Attribution (CC BY) license (http://creativecommons.org/licenses/by/4.0/). 